\title{
Litho chemical Prospecting for Gold Mineralization In Duweishat Mine Area-Northern Sudan
}

\author{
* Dr. Younis Suliman Mostafa
}

\begin{abstract}
The studied locality lies in North state of arid to semi-arid climate, where physicalmechanical weathering and denudation processes dominate. The lithostratgraphic sequence in geochronological order (from bottom to top) as high-grade gneisses, low-grade metasedments, serpentinized altrabasic (ophiolite complex) rocks, and younger granitoidal intrusions.

Results which were obtained for $\mathrm{Au}$ and accompanying elements (Ag, Co, $\mathrm{Cu}, \mathrm{Pb}$, and $\mathrm{Zn}$ ) were subjected to statistical analysis to reveral parameters such as (background value $(\mathrm{Cb})$, coefficient of correlation, coefficient of variation, geochemical factors, productivities, and coefficient of dispersion). Sampling of residual soil was found to be effective in prospecting to reveal anomalous contents of chemical elements in the study area.

Statistical methods interpretation of data proved to be effective and complement each other. The coefficients of correlation of Au with the accompanying elements in chip composite samples show values more reliable values for prospecting than those of the soil samples.

Gold dispersion in the study area shows erratic behavior. The other mobile elements are dispersed around the mineralized quartz veins. The morphology of secondary dispersion halos of ore elements reflects more or less the morphology of the hidden ore bodies Coefficients of correlation when they are reliable can be used to define pathfinder to prospect for difficult gold. Geochemical factor can indicate horizon of mineralization and level of weathering.
\end{abstract}

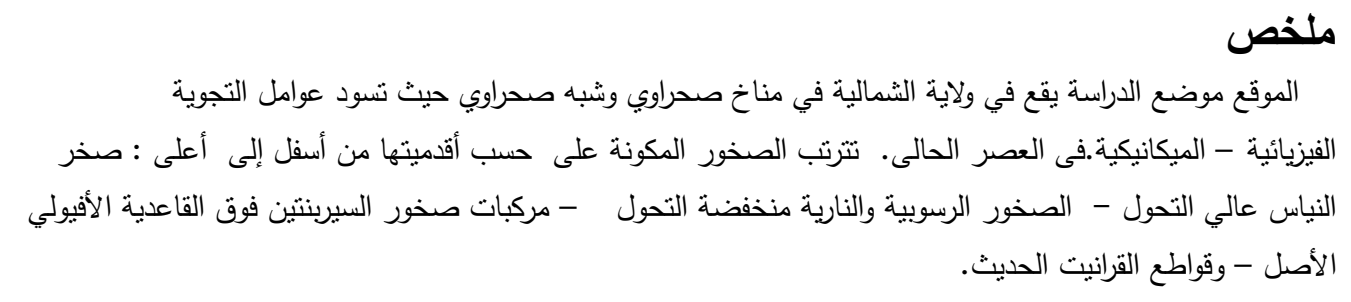

* Faculty of Engineering Sciences-Omdurman Islamic University 


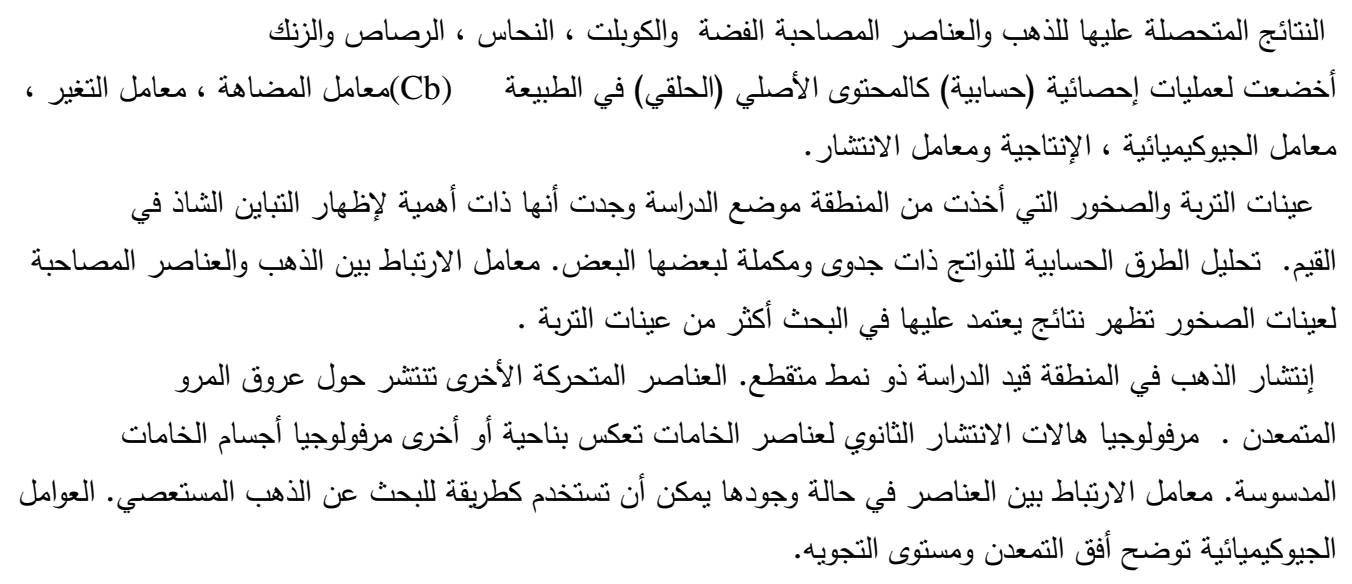

\section{Introduction}

Duweishat area is situated south of the Sudan -Egypt Border line, at about $3.5 \mathrm{~km}$ east of the River Nile, and $62 \mathrm{~km}$ south west of WadiHalfa town, at the intersection of the coordinate: latitudes $21^{\circ} 22^{\prime} 15^{\prime}$, longitude $30^{\circ} 50^{\prime} \mathrm{E}$. The River Nile and constitute the main drainage system. The pattern of the dry vallies is denderitic type.There are no tributaries of the River Nile but branches. This drainage usually follows certain structures such as faulting and shearing. In the banks of the Nile drainage is steep and deeply incised into a series of narrow gorges, and steep - sided Wadis which are usually flooded during flood seasons.

The area, like most of the other present-day desert areas has been subjected to climatic fluctuation during its prolonged geological history. The last humid climates prevailed in Sahara area was in the late Paleocene (Holocene) Matheis (1985). Lateritic soil cover observed in many localities and thick relics of unconsolidated sediments along terraces of the wadis are features to support this believe. Alternating periods of relatively humid, semiarid, and fully arid conditions over the past 50000 years have been revealed. Angular unsorted components ranging from clayey fractions to very coarse gravels have been recorded. The deposition of these sediments was due to heavy rainfall that drained dirt surface run-off in a very short time, producing sheet floods of enormous transportation energy. An emphases should be made on areas which had been subjected to paleoclimatic conditions e.g. buried 
rivers and channels. The River Nile itself, since its first appearance on this part of the crust, has changed its course and direction several times.

The present dispersion of chemical elements in the area is not due to present day climatic conditions, but due to palcogeochemical cycles of trace elements in the past.

\section{Previous Work}

Duweishat area had been one of the ancient Pharonic gold mines. Generally Artifacts and mining pits are used as criteria to prospect for gold mineralization zones in the Northern and NE parts of the Sudan. Dunn (1911), who visited the area early in the last century, wrote unfavorably on the prospect. He reported evidence of ancient mining activity at Duweishat to a maximum depth of 10 meters.

Foly (1950), a consulting mining Engineer did some sampling on the existing ore pits left by the old miners and from five representatives composite samples taken from different locations gave a result of $0.306-0.45$ of troy once/ton.

According to Whiteman (1971) modern mining in two locations in Duweishat area started in (1905). Local people who were involved in the mining of Duweishat witnessed that during the year 1962 four different main outcrops of gold-bearing quartz veins were mined contemporaneously by about 550 men in open pits and underground workings. The depth of the underground workings was $170 \mathrm{~m}$ for Shaft No.1, $50 \mathrm{~m}$ for Shaft No. (2), 10m for Shaft No.(3), and $130 \mathrm{~m}$ for Shaft No.(4). Mining was resumed in the area by El Fadil Mahdi Company during 1951-1962. In 1985 BONIFICA wrote a report on primary and alluvial gold deposits along Nile valley (Khalil, B.E.1993, 1996). The United Nation Project was carried out in 1987 on mineral exploration of the Egypt-Sudan Area of Integration. Later the area has been visited by Stern and others who described the regional geology and did the first systematic geochronological work (Stern et. Al., 1993).

Since 1997 the area has been licensed to La Source a French Company, for gold exploration. Geological mapping and only limited emphasis was directed towards the metallogenic evolution of the area. 


\section{Aim of the Work}

This study is meant to be an orientation study in lithochemical methods to prospect for gold in arid and semi arid geochemical landscapes. Already known area of gold mineralization was selected for this experimental study. The main objective was to reveal quantitative geochemical prospecting criteria, which can be applied for areas of similar climatic, geochemical and geotectonic environments. T his is planed to be tackled through soil and rock sampling in gold mineralized areas. Residual (eluvial, deuvial) soils are sampled to reveal secondary dispersion pattern of gold mineralization i.e secondary dispersion haloes (S.D.H) And secondary dispersion drainage pattern (S.D.D.P) Composite rock chip samples were collected to show distribution of gold and affiliated elements in suspected loads and the surrounding country rocks.

\section{Geology}

The area is underlain by variety of rocks of Precambrian Basement complex that include metavolcanic and metasedimentry sequences which dominantly consist of calcareous and marble bands forming prominent, stauralite- garent micaschist, in addition to subordinate biotite gneisses and granitic gneisses. Grades of metamorphism range from greenschist to amphibolite facies. These sequences are generally repeated throughout the area. All the members were intensively sheared and overturned.

Stern, et al (1993) interpreted that the basement around Wadi Halfa is composed of five principal lithologies a strongly foliated gneisses (Duweishat gneisses) overlain by mafic metavolcanic, metasedimentary and felsic metavolcanic. These are intruded by syntectonic grandiorite and post tectonic alkali granite. In the Northeastern part of the prospect the calcareous garnetmicaschist are the host rocks of a auriferous quartz veins.

In the Southeastern sector the host of gold are metavolanics rocks which include meta-tuff.

The auriferous quartz veins of Duweishat area are mainly lens-shaped cutting in Precambrian Basement rocks which consists of layered sequences of banded marbles, locally showing subparrallel of calc- silicates rocks, biotitegneisses. 
مجلة العلوم الهندسيةــ العدد الثالثـ - 2008

\section{Geochemistry}

The target area, falls within desert, semi-desert terrain where importance contrast represents the main agent of weathering.

Supergene dispersion and accumulation of elements within the geochemical landscape has been governed by the geological, geomorphological, and climatic factors.

Superficial deposits are derived directly from primary host rocks with their primary enclosed mineralization. Areas of local anomalous gold content (concentration), recorded as local small placer deposits, and could be a result of more than one cycle of dispersion. A combination of these processes and their inter-relation at or near the surface, since mineralization time in Precambrian, governs trace elements dispersion and migration.

The first stage of weathering started with changing of rocks from massif into clastic state forming coarse and fine grained detrital material. Eluvium which is a destingrated material of weathering accumulates in situ, with fine grained material being transported mostly by wind action.

Geochemical parameters, describe qualifical landscape. The distribution of chemical elements in certain geochemical environment is governed by geological processes, such as primary mineralization, secondary dispersion or secondary concentration

Interpretation of analytical results of residual soil sampling along profile is expected to reveal, Secondary Dispersion Haloes while results of composite chip samples, whether along profiles or haphazardly collected are expected to characterize Primary Aureoles of the gold-bearing orebodies.

In this study an attempt has been made to quantify geochemical criteria expected to be revealed as a result of orientation study. These criteria are to be used to prospect and to explore for gold mineralized orebodies which are either outcroping on surface but with unseen mineralization, buried by unconsolidated and consolidated younger deposits or blind orebodies.

Sampling included massive rock specimens, chip rock samples, and unconsolidated soil material.

Solid rock specimens were collected along geotraverses from different lithological units. Samples were fresh and representative specimens were collected for petrographic mineralogical studies and chemical analyses. Rock sampling was undertaken during orientation traverses in every mapable unit. 
Each rock sample was about $1000 \mathrm{gm}$ in weight. The samples were collected largely to define the geology of the area.

Fresh fragments $(2.5 \mathrm{~cm}$ in diameter) were taken along the same profiles, which were used to collected residual soil samples on mineralized zones, Each samples represents a composite chip samples taken across recognizable unit; average weight is of about 1500 gram.

\section{Statistical Work}

Analytical results are interpreted by geostatistical methods using relevant geostatistical Computer programs to reveal quantitative litho chemical prospecting criteria such as coefficient of dispersion, a criteria to define the optimum sampling interval and optimum fraction of soil samples, univarant, and bivarint coefficients of correlation analysis, to work out elemental mineralogical assemblages, elemental associations, and pathfinders according to different levels of confidence (probabilities, geochemical factors)i.e. ratios of contents of chemical elements to define horizon of mineralization, level of weathering and expected blind shallow gold mineralized bodies, liner (M), aerial $(\mathrm{P})$, and geochemical productivity $(\mathrm{q})$ or geochemical reserve $(\mathrm{QH})$ of ore bodies for different localities were estimated.

These geochemical parameters when subjected to conventional geostaistical analysis can be defined and used as prospecting and exploration criteria. The parameters considered this study are:

1. Back ground value $(\mathrm{Cb})$.

2. Coefficient of correlation (r)

3. Coefficient of dispersion (mobility) $\delta$.

4. Coefficient of variations of elements (CV).

5. Geochemical factors $(\mathrm{U})$.

6. Productivity $(\mathrm{P})$ and geochemical reserve $(\mathrm{OH})$.

As mentioned earlier, the main objective of this study is to interpret the results revealed, so as to define quantitatively parameters which may be used as prospecting and explorational criteria to search for gold concentration in arid-semi arid climatic conditions (Zeeger et al 1985). These results are discussed below. 
The high standard deviation for gold reflects the erratic distribution of this element. This element is necessary that in prospecting residual soil sampling should follow detailed scale. The other elements subjected to chemical and statistical treatments are $\mathrm{Ag}, \mathrm{Cu}, \mathrm{Pb}$, and $\mathrm{Zn}$ (table No1). These are the only elements, which could be analyzed.

High background values for $\mathrm{Zn}$ and $\mathrm{Pb}$ is explained to be due to supergene enrichment during digenesis of the minerals containing these elements. These minerals were sulphides, oxides, carbonates and silicates.

In Duweishat area the calculation of the Coefficient of correlation of gold with the elements $\mathrm{Cu}$ and $\mathrm{Pb}$ is weak $(\mathrm{r}-0.16$ and 0.26$)$ respectively. Weak negative correlation with $\mathrm{Ag}$ and $\mathrm{Zn}(\mathrm{r}=-0.23,-77)$ is also observed table No. (2).

The analysis of variance of trace elements in Duweishat area:

$\mathrm{C}, \mathrm{V}=(\mathrm{s} \sqrt{\mathrm{x}}, 100 \%)$ of lead, zinc, copper, silver and gold on $25 \mathrm{~m}$ interval sampling as defined by the above formula, have large components of variations $75 \%, 69 \%, 83 \%$, and $16.2 \%$ respectively table No.(1). These variations reflect non-uniform distribution of elements.

\section{Interpretation of the Results}

Table (1)

\begin{tabular}{|l|c|c|c|c|c|}
\hline & $\mathbf{A u}$ & $\mathbf{A g}$ & $\mathbf{C u}$ & $\mathbf{P b}$ & $\mathbf{Z n}$ \\
\hline Mean & 1.94 & 6.4 & 59.37 & 79.42 & 282.1 \\
\hline Maximum & 13.5 & 23 & 185 & 311 & 6.58 \\
\hline Minimum & 0.2 & 1 & 19 & 5 & 42 \\
\hline Range & $13.5-0.2$ & $23-1$ & $185-19$ & $311-5$ & $658-42$ \\
\hline Variance & 9.65 & 29.27 & 216.57 & 3537.87 & 37341.7 \\
\hline Standard deviation & 3.14 & 5.41 & 64.57 & 59.78 & 193.2 \\
\hline $\begin{array}{l}\text { Coefficient of } \\
\text { variation }\end{array}$ & $16.2 \%$ & $83 \%$ & $78 \%$ & $75 \%$ & $69 \%$ \\
\hline Threshold & 8.22 & 17.22 & 152.6 & 198.4 & 668.6 \\
\hline Number of sample & 19 & 19 & 19 & 19 & 19 \\
\hline
\end{tabular}




\subsection{Geomorphology of Secondary Dispersion Haloes}

In Duweishat area, analysis of residual soil samples have revealed significant dispersion of the ore and accompanying elements. The standard deviation and coefficient of variation is typical of erratic mineralization.

The morphology of the secondary halo is controlled by the morphology of the ore body. The down slope of the outcropping quartz vein is towards the $\mathrm{NE}$ direction, the erratic results of gold suggest that dispersion is clastic within scree developed on the slopes.

In Duweishat area gold values tend to form irregular high grade zones or shoots, which are separated by areas of lower grade mineralization or barren quartz. This is clearly seen in anomalous gold values $(=2 \mathrm{~g} / \mathrm{t})$ of the secondary dispersion haloes that occur through the vein system. Significant values tend to concentrate around old shafts.

Investigation of the geological anomalies shows that many of the anomalous gold samples could be related to the known gold-bearing outcrops, and reflects the direct down hill transport of deterial gold by gravity. The dispersion patterns appeared to be formed dependently of the present day topography.

Traversal gold values decreases to background about $200 \mathrm{~m}$ towards the base of the slope. Concentration reaches $13 \mathrm{ppm}$, at which the aureoles are closed.

\subsection{Coefficient of Correlation ( $r)$}

The insignificant of correlation of gold with these elements may be partially due to the unrepresentitve nature of samples. The main reason is most due to clastic dispersion nature of these elements (Said, A.M1994).

Coefficient of correlation of trace elements of quartz veins chip samples table (No. (3)) shows reliable correlation to the residual soil samples, because the former example is not yet subjected to diagnesis. 
Table (2): Coefficient of Correlation of Elements of Duweishat Residual Soil samples of Quartz Veins (deluvial, elivial).

\begin{tabular}{|lccccc|}
\hline & $\mathrm{Au}$ & $\mathrm{Ag}$ & $\mathrm{Cu}$ & $\mathrm{Pb}$ & $\mathrm{Zn}$ \\
\hline $\mathrm{Au}$ & 1 & -0.23 & 0.16 & 0.26 & -0.77 \\
$\mathrm{Ag}$ & & 1 & 0.01 & -0.16 & 0.44 \\
$\mathrm{Cu}$ & & & 1 & 0.58 & 0.15 \\
$\mathrm{~Pb}$ & & & & 1 & -0.33 \\
$\mathrm{Zn}$ & & & & & 1 \\
\hline
\end{tabular}

Table (3): Coefficient of correlation of elements of Duweishat quartz veins

\begin{tabular}{|lccccc|}
\hline & $\mathrm{Au}$ & $\mathrm{Ag}$ & $\mathrm{Cu}$ & $\mathrm{Pb}$ & $\mathrm{Zn}$ \\
\hline $\mathrm{Au}$ & 1 & 0.4 & -0.002 & -0.4 & -0.07 \\
$\mathrm{Ag}$ & & 1 & -0.58 & 0.6 & 0.2 \\
$\mathrm{Cu}$ & & & 1 & -0.7 & 0.12 \\
$\mathrm{~Pb}$ & & & & 1 & -0.1 \\
$\mathrm{Zn}$ & & & & & 1 \\
\hline
\end{tabular}

\subsection{Geochemical Factor (v)}

The ratio of epithermal (low temperature) to the hypothermal (high temperature) elements in this area summarized the geochemical landscape.

These ratios also help in determination of mineralization horizon, or weathering level (said, A.M 1994.) , Gold to silver ratio (AU/Ag) (Table 5) varies considerably in all over the sampled part of the mineralized zone, but generally this ratio is low, with slight increase towards the SW direction. Hence by this one to one element ratio, in its present form is not enough to predict for the special behavior of the mineralogical body neither laterally nor at lower depth. This is why a second ratio is considered, (Table 5). Geochemicaly this ratio describes the distribution of $\mathrm{Pb}, \mathrm{Zn}$, and $\mathrm{Au}, \mathrm{Cu}$. Low temperature elements $\mathrm{Pb}, \mathrm{Zn}$, (epithermal) to higher temperature (mesothermal) elements $\mathrm{Au}, \mathrm{Cu}$, This ratio shows generally higher values with monomotonous 
decrease towards the SW direction Based on the general concept that the temperature of the hyprothermal mineralogy decreases. This has been confirmed also by higher absolute values of $\mathrm{Au}$ content in the southwestern parts of the ore body where the secondary ratio is still open see Figure (1).

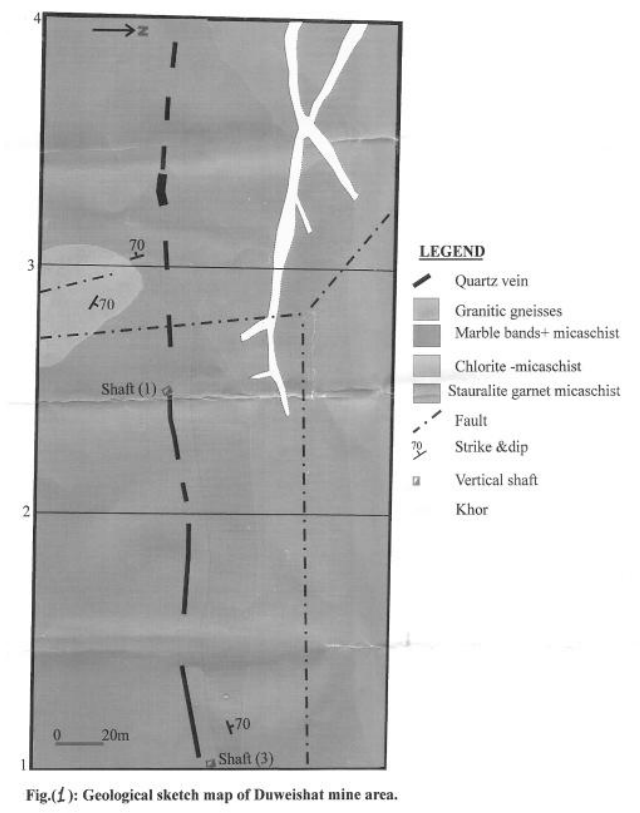

Figure (1)

\section{The Coefficient of Mobility (Dispersant $\delta$ )}

The value of coefficient of mobility ( $\delta$ ) of the elements $\mathrm{Au}, \mathrm{Ag}, \mathrm{Pn}, \mathrm{Zn}$, and $\mathrm{Cu}$, were calculated for elements with highest value be equal to $9,7,9$, 13 , and 7 meters respectively Zinc is the element with the highest value.

From the above it is clear that coefficient of mobility is governed by topography and geomorphology of the ore body and the country rocks (Wester et al 1984) rather than the geochemical characteristics of the elements since the study area is located more or less in arid-semi arid geochemical landscape. 
This explains why coefficient of motilities of the elements in Duwiesat is high. Hence sampling interval, a part from the geochemical character of the elements, should consider the topography and geomorphology characteristics of the study area. According to Solovov (1965),Khalil,(1973).. The coefficient of mobility decreases with depth towards the lower boundary of the zone of weathering.

\section{Productivity}

The geochemical reserves $(\mathrm{QH})$ of the elements $\mathrm{Au}, \mathrm{Cu}, \mathrm{Pb}$, and $\mathrm{Zn}$ are displayed in table No (4).

Gold is the main ore elements, others are accompanying. The productivity $(\mathrm{P})$ of $\mathrm{Au}$ and the amount of metal for a laryer 1 meter thick, .

The depth (vertical continuity of the mineralized vein $(\mathrm{H})$ is considered to be one third of its horizontal length. Hence the geochemical reserve for gold according to relationship is:

$\mathrm{q}, 1 / \mathrm{k}, \mathrm{H}(\mathrm{C} . \mathrm{F})=\mathrm{QH}$., $\mathrm{q}$ is found to be $0.11 \mathrm{ton} / \mathrm{m} ., \mathrm{k}=1.5$, $\mathrm{H}=330$, Hence $\mathrm{QH}=49.5$ ton. Au.

This study represents a preliminary assessment of the economic potentialities of the quartz veins that exposed on surface. The ore reserve must be substantially increased through more detailed prospecting and exploration works.

The surface exposure of Duweishat is outlined by a 1 by $2 \mathrm{~km}$ of a boundinaged or body.

Table (4): Geochemical reserves of $\mathrm{Au}, \mathrm{Ag}, \mathrm{Cu}, \mathrm{Pb}$, and $\mathrm{Zn}$ of Duweshat Mineralization zone:

\begin{tabular}{|c|c|c|c|c|c|c|}
\hline $\begin{array}{c}\text { Chemical } \\
\text { elements }\end{array}$ & $\mathbf{C b}$ & $\mathbf{C A}$ & $\mathbf{q}$ & $\mathbf{K}$ & $\mathbf{H}$ & $\mathbf{Q H}$ \\
\hline & $\%$ & $\%$ & $\mathrm{~T} / \mathrm{m}$ & & $\mathrm{M}$ & $\mathrm{Ton}$ \\
\hline $\mathrm{Au}$ & $1.94 \times 10^{6}$ & $1.2 \times 10^{6}$ & 0.11 & 1.5 & 330 & $5 \mathrm{j} 49$ \\
\hline $\mathrm{Ag}$ & $6.4 \times 10^{6}$ & $18 \times 10^{6}$ & 0.12 & 1.3 & 330 & 196 \\
\hline $\mathrm{Cu}$ & $45 \times 10^{6}$ & $1.30 \times 10^{6}$ & 0.02 & 1.1 & 330 & 1764 \\
\hline $\mathrm{Pb}$ & $75 \times 10^{6}$ & $240 \times 10^{6}$ & 1.2 & 0.9 & 330 & 2681 \\
\hline $\mathrm{Zn}$ & $225 \times 10^{6}$ & $.380 \times 10^{6}$ & 1.8 & 0,0 & 330 & 4245 \\
\hline
\end{tabular}


Table (5): Chemical Analysis of Duweishat Trace Elements Residual Soil Samples:

\begin{tabular}{|l|c|c|c|c|c|c|c|}
\hline $\begin{array}{l}\text { Sample } \\
\text { No }\end{array}$ & Au & Ag & $\mathbf{Z n}$ & $\mathbf{C u}$ & $\mathbf{P b}$ & $\frac{\mathbf{P b} \cdot \mathbf{Z n}}{\mathbf{A u .} \mathbf{C u}}$ & $\mathbf{A u} / \mathbf{A g}$ \\
\hline $\mathrm{D}_{1}$ & 0.8 & 8 & 83 & 132 & 97 & 76.6 & 0.1 \\
\hline $\mathrm{D}_{2}$ & 0.4 & 7 & 498 & 185 & 91 & 61.2 & 060. \\
\hline $\mathrm{D}_{3}$ & 0.7 & 8 & 210 & 75 & 71 & 264.4 & 0.06 \\
\hline $\mathrm{D}_{4}$ & N.D & 8 & 210 & 22 & 87 & - & - \\
\hline $\mathrm{D}_{5}$ & 0.7 & 7 & 214 & 24 & 82 & 106.8 & 0.01 \\
\hline $\mathrm{D}_{6}$ & N.D & 8 & 63 & 24 & 70 & - & - \\
\hline $\mathrm{D}_{7}$ & 0.3 & 9 & 62 & 25 & 86 & 71.9 & 0.03 \\
\hline $\mathrm{D}_{8}$ & 0.6 & 8 & 315 & 48 & 51 & 523.1 & 0.08 \\
\hline $\mathrm{D}_{9}$ & 0.5 & 8 & 521 & 30 & 51 & 1771 & 0.05 \\
\hline $\mathrm{D}_{10}$ & 0.3 & 9 & 418 & 48 & 59 & 184.7 & 0.03 \\
\hline $\mathrm{D}_{11}$ & 4.9 & 9 & 518 & 36 & 5 & 13.8 & 0.54 \\
\hline $\mathrm{D}_{1} 2$ & 1.97 & 23 & 658 & 63 & 66 & 35 & 0.09 \\
\hline $\mathrm{D}_{13}$ & 6.9 & 2 & 91 & 151 & 311 & 27.1 & 3.5 \\
\hline $\mathrm{D}_{14}$ & 0.2 & N.D & 206 & 66 & 74 & 1154.8 & - \\
\hline $\mathrm{D}_{15}$ & N.D & N.D & 417 & 45 & 60 & - & - \\
\hline $\mathrm{D}_{16}$ & 2.2 & 6.6 & 249 & 42 & 60 & 161.6 & 0.33 \\
\hline $\mathrm{D}_{17}$ & 13.5 & N.D & 42 & 40 & 64 & 4.97 & - \\
\hline $\mathrm{D}_{18}$ & 1.6 & 1 & 446 & 55 & 63 & 319.2 & 0.6 \\
\hline $\mathrm{D}_{19}$ & 1.2 & N.D & 87 & 19 & 58 & 221.2 & - \\
\hline
\end{tabular}

Table (6): Chemical Analysis of Trace Elements of Chip Samples of Duweishat Area:

\begin{tabular}{|l|c|c|c|c|c|}
\hline Rock type & Au & $\mathbf{A g}$ & $\mathbf{C u}$ & $\mathbf{Z n}$ & $\mathbf{P b}$ \\
\hline Quant type & 1.5 & N.D & 80 & 25 & 37 \\
\hline Quartz vein & 50.1 & 4 & 20 & 38 & 43 \\
\hline Quartz vein & 6.6 & N.D & 53 & 151 & 38 \\
\hline Marble & 6 & N.D & 50 & 27 & 84 \\
\hline Quartz vein & 0.3 & 1 & 15 & 38 & 394 \\
\hline Mylonite & 5.3 & N.D & 35 & 23 & 48 \\
\hline Quartz vein & 1.3 & N.D & 29 & 139 & 445 \\
\hline
\end{tabular}

Zn: The dispersion of $\mathrm{Zn}$ differs from gold where the first displays a typical hydromorphic distribution pattern. However $\mathrm{Zn}$ shows systematic variation pattern and formed enrichment around the deposits, where dispersion of $\mathrm{Zn}$ form a halo surrounding the high grade zone where concentration is reaching 
$650 \mathrm{ppm}$, with mean value equals to (282 ppm), with range of $616 \mathrm{ppm}$ and standard deviation as $193 \mathrm{ppm}$.

Ag:

Silver concentration in the ore zone shows constant values, varing between 7-9 ppm. Nevertheles increased values of Ag over the deposit is detected in limited number of localities over the primary source. The poor content of Ag is believed to be due to more recent depletion.

Cu:

Copper shows enrichment zone around the deposits. On the slopes of the quartz veins the aureole is closed. Because of the high mobility of the element.

\section{Conclusions}

1- The revailed secondary dispersion patterns of gold (the main ore elements) and the affiliated accompanying elements indicate prolonged and variable conditions.

2- Gold dispersion shows erratic distribution. The other mobile elements are dispersed around the mineralization quartz veins. Nevertheless the isoconcentrate maps of the ore elements $(\mathrm{Au})$ and those of accompanying elements are elongated concordantly along the auriferous quartz veins. Hence the morphology of secondary dispersion halos of both the ore element and accompanying elements reflect more or less the morphology of the hidden primary ore bodies.. The correlation coefficient for residual soil samples is not a useful parameter. Chip-composite rock samples should be collected for all the exposed ore bodies.

3- The revealed geochemical parameters for Duweishat area, when quantified can be used as prospecting criteria.

4- Geochemical factors or the ratios of contents of epithermal elements (low temperature) to those of hypothermal elements (high temperature) can indicate the horizon of mineralization as well as the weathering level of the sampled ore body. This is believed to be a common feature of the other ore bodies which occur along the River Nile in Bayuda Desert.

5- The variation in the distribution of gold increases with depth. Deep weathering had mobilized and concentrated the gold in the zone of secondary enrichment in the water table. 
6- Gold geochemical reserves of Duweishat area is calculated to be 49.5. Tons. This is not to the actual geological reserve of gold, but only geochemical dispersion of primary ores. These mathematical expression $(\mathrm{OH})$ is considered to be usual parameter to quantify, with others, the mother load.

\section{References}

1. Abdel Rahman, E, M. (1993): Geochemical and geotectonic of the metallogeny of selected ophiolite complexes from the Sudan-Berl. Geowiss. Abh.(A) 159, 103 PP., Berlin.

2. Aloub, O.A., and El Samani., Y. (1991): The geology of golddepsite in the Red Sea HILLS OF THE Sudan. Pan-African Tectonic- Metamorplic Models. Gold Res. Authority of theSudan (GRAS), Bulten No.39.

3. Bakheit, A.K. (1991): Geochemical and structural control of sulfidegold mineralization in Ariab mineral district, Red Sea Hills-Sudan, Ph.D., thesies (unpubl.).

4. BONIFICA Geoexport Roma. (1986) Reconnaissance, Primary and Alluvial Gold Deposits along the Nile Valley, report No.3 in Hydrogeological studie and investigation in North Sudan.

5. Dennant, C.B., and White, M.I (1959): Study of the distribution of some geochemical data: Econ. Geol. V.54, P1281-1290. Vol. B: Annex (Geochemical data)-Unpubl.Rep., BGR, Hannover.

6. -Dunn, S.C. (1911): Notes on the mineral deposit of the Anglo-Egytian Sudan. Goal. Sur. Bull., no.1: Khartoum.

7. -Gareth, R, G, and N (chol, I, (1969): Factor analysis as an aid in the interfectation of regional geochemical stream sediment data..Quartary of the color such. Mines, N, 64, No.1, P, 245-264.

8. -Khalil,B.E.,(1973):Quantitative interpretation of secondary dispersion patterns of gold deposits in the Red Sea Hill ,Bull.Geol. Miner.Resour.Sudan, 24,63pp. 
9. -Khalil,B.E.(1996):Geochemical criteria to prospect for mineral deposits in crystalline basement of the Sudan proceed. In conf..On. Geosc..Res.North. Afreica, Thorweihe.

10. -Matheis, G., (1985): Paleo-dispersion in Wadi drainage and its potential prospecting Application, special Researsh-project. Arid areas, Technical Univ. of Fedral Republic of Germany, p.209-213.

11. -Nichoil, I., Garret, R.G., and Webb, J.S. (1967): The role of some statistical and mathematical methods in the interpretation of regional geochemical data. Econ., Geolo. V.64, P. 204-220.

12. Said .A. M. (1994): Geochemical calculation of trace element pattern in literature soils above late prophetic basement units of Nigeria West Africa. Berbr Geowise Abh.(A) 169.103PP. Berlin.

13. SOLOVOV, A.Q.(1965) : Geochemical Methods of ore deposite exploration by its secondary halos and dispersion flows state geological committee of U.SS.R.MOSCOW.

14. Stern.R.J, kroner, A., Reishman, T., Bender, k., and Dawoud, A.s.(1993): Precambrian basement around Wadi Halfa, A new perspective on the evaluation of the central saharan Ghost craton.Special volume on Geoscientific Reser. Geologische Rundschan.

15. Wester J.G.S and Mann, A.W.(194) The influence of climate, geomorphology and primary geology on the supergene migration of gold and selector geochemic Ephrr.22, p, 21,24.

16. Witewman, A.j (1971): The geology of the Sudan Republic. Oxford. Clareendan Press, P.290. 